\title{
Effect of Quinapril, Quinapril- Hydrochlorothiazide, and Enalapril on the Bone Mass of Hypertensive Subjects: Relationship With Angiotensin Converting Enzyme Polymorphisms
}

\author{
José L. Pérez-Castrillón, Jesús Silva, Isabel Justo, Alberto Sanz, \\ Miguel Martín-Luquero, Rosa Igea, Pilar Escudero, Carol Pueyo, \\ Cristina Díaz, Gonzalo Hernández, and Antonio Dueñas
}

\begin{abstract}
Background: Many alterations in extracellular metabolism of calcium have been associated to hypertension, but the number of studies relating this disease with osteoporosis is extremely low. This study clarifies the therapeutic effect of three treatments-quinapril, quinapril + hydrochlorothiazide (HCTZ), enalapril-on bone remodeling markers, bone mineral density (BMD) in hypertensive patients, and relationship with angiotensin converting enzyme (ACE) polymorphism.
\end{abstract}

Methods: This open, prospective study included 134 patients with low-to-moderate hypertension and stable BMD according to Joint National Committee criteria and 96 patients completed the study. After a washout period, patients were randomized to one of the three treatments, which they received for 1 year. Analyses of blood and urine samples and densitometric studies on lumbar spine were performed.

Results: Calcium and 25-hydroxyvitamin $\mathrm{D}$ levels increased $(9.5 \pm 0.3$ and $9.6 \pm 0.3 \mathrm{mg} / \mathrm{dL}, P=.01$ and 46 \pm 22 and $58 \pm 22 \mathrm{nmol} / \mathrm{L}, P=.026$, respectively) in the quinapril-treated group and calcium levels increased ( 9.4 \pm 0.6 and $9.8 \pm 0.4 \mathrm{mg} / \mathrm{dL}, P=.001)$ in the quinaprilHCTZ-treated group. The 1, 25-dihydroxyvitamin D lev- els, calciuria, and calcium/creatinine ratio decreased (64 \pm 23 and $43 \pm 16 \mathrm{nmol} / \mathrm{L}, P=.0001 ; 209 \pm 93$ and 161 $\pm 93 \mathrm{mg} / 24 \mathrm{~h}, P=.0022 ; 0.21 \pm 0.09$ and $0.17 \pm 0.11, P$ $=.04$, respectively). In the enalapril-treated group 1,25 dihydroxyvitamin D levels $(61 \pm 27$ and $42 \pm 19 \mathrm{nmol} / \mathrm{L}$, $P=.0022$ ) decreased. Only women presented a statistical significance $\left(1.064 \pm 0.16 \mathrm{~g} / \mathrm{cm}^{2}, P=.034\right)$ between ID+II polymorphism and BMD decrease, and between DD polymorphism with less BMD under baseline conditions and a BMD increase $\left(1.070 \pm 0.16 \mathrm{~g} / \mathrm{cm}^{2}, P=.017\right)$ after ACE inhibitor treatment.

Conclusions: The ACE inhibitors have a beneficial effect on BMD and calcium metabolism alterations in hypertensive subjects. Concerning BMD response, women presenting with the II+ID polymorphism had a poor response to antihypertensive drug treatment, whereas women with the DD polymorphism responded better. This is the first study demonstrating a relationship between ACE polymorphism and BMD response and antihypertensive ACE inhibitor treatment. Am J Hypertens 2003;16: 453-459 (C) 2003 American Journal of Hypertension, Ltd.

Key Words: Hypertension, bone mass, quinapril, enalapril, I/D polymorphism of ACE.
B oth hypertension and osteoporosis are clinically silent diseases. Their financial and social cost is determined by their consequences, such as vascular illnesses in hypertension and fractures in osteoporosis. The relationship between these illnesses has not been clearly established, although many alterations in extracellular metabolism of calcium, which could determine the level of bone mineral density (BMD) in these patients, have been associated to hypertension. These alterations include decrease in ionic calcium, increase in calciuria and
Received October 10, 2002. First decision January 8, 2003. Accepted February 4, 2003.

From the Departamento de Medicina Interna (JLP-C, JS, IJ, MM-L, RI, PE, AD), Hospital Universitario Río Hortega; Laboratorio de Pedia- tría, Departamento de Pediatría-IBGM (AS), Facultad de Medicina de Valladolid, Valladolid; and Pfizer (CP, CD, GH), Madrid, Spain.

Address correspondence and reprint requests to Dr. José L. PérezCastrillón, Hospital Río Hortega, Cardenal Torquemada s/n, 47010 Valladolid, Spain; e-mail: castrv@terra.es 
urinary cyclic adenosine $5^{\prime}$-monophosphate, increase in parathyroid hormone (PTH) serum concentration and calcitriol in plasma, and increase in calcium intestinal absorption. ${ }^{1-6}$ Despite these alterations, the lack of studies relating these two important diseases is surprising, and hypertension is not identified as a risk factor for osteoporosis. Cappuccio et $\mathrm{al}^{7}$ studied the relationship between BMD and blood pressure (BP) in white women, finding an inverse association between those two parameters, but only with the highest BP values.

The effect of antihypertensive treatment on the phosphorus and calcium metabolism of these patients is another interesting aspect, especially considering that $50 \%$ of the hypertensive population consists of postmenopausal women. ${ }^{7}$ Due to their calcium-saving effect, the use of thiazides is beneficial, although very few studies using other drugs have been conducted. ${ }^{8}$ In a 12-week trial, quinapril, an angiotensin converting enzyme (ACE) inhibitor, reduced calciuria by $15 \%$. However, this finding was underestimated because no other parameters of phosphorus and calcium metabolism or bone mass were assessed. ${ }^{9}$ A polymorphism (I/D) of ACE has been described. ${ }^{10}$

Muscular activity has been related to ACE polymorphism by associating the presence of allele I to a higher muscular contraction capacity and a higher response of BMD to substitutive hormonal treatment. ${ }^{11}$

This study was designed to determine the effect of three therapeutic regimes (quinapril, quinapril + hydrochlorothiazide [HCTZ], and enalapril) on bone remodeling and BMD markers in hypertensive subjects during a 1-year follow-up. We tried to determine whether there was a relationship between these effects and the I/D polymorphism of the angiotensin-converting enzyme. Quinapril and HCTZ were used because of their calcium-saving effect, whereas enalapril was used as an ACE inhibitor comparator.

\section{Methods Subjects and Study Protocol}

This study included 134 patients ( 82 women and 52 men), aged between 36 and 76 (average age $59 \pm 10$ years), with systolic or diastolic stage I-II hypertension, according to Joint National Committee VI criteria. After a 2-week washout period, patients were randomly allocated to one of the three treatments: quinapril $(40 \mathrm{mg} /$ day $)$, quinapril (40 mg/day) plus HCTZ (12.5 mg/day), and enalapril (20 $\mathrm{mg} /$ day). No baseline differences were observed in patients other than their genotype. Patients were monitored for 1 year and they were seen every 3 months. Ninety-six patients completed both the first and the last visit. Patients with the following conditions were excluded from participation in the study: ethylism, neoplasia, secondary arterial hypertension, chronic renal insufficiency, hyper- and hypocalcemia, diabetes, hyperparathyroidism, and use of drugs modifying BMD (calcium, vitamin D, estrogens, calcitonin, bisphosphonates, fluorine). The average time for the development of hypertension was $65 \pm 84$ months. Seventy-four women were postmenopausal (90\%). An untreated control group of hypertensive patients was not included due to ethical reasons.

\section{Measurements}

Blood samples were collected between 8 and 9 hours after fasting all night. Total calcium, phosphorus, magnesium, and alkaline phosphatase were measured with a Hitachi 917 auto analyzer (Tokyo, Japan). Ionic calcium and ion (sodium, creatinine, calcium, and phosphorus) levels in urine were assessed in a device equipped with an ionselective electrode (Nova-7, Nova Instruments, Walthman, MA). Osteocalcin was measured using a commercial radioimmunoassay test (Schering, Berlin, Germany) with a $6.7 \%$ interassay variation coefficient. Intact PTH (PTHi) levels were determined by chemiluminescence (Immulite DPC, Los Angeles, CA) with a $6 \%$ variation coefficient. The 25-hydroxyvitamin D levels were measured by HPLC with $12 \%$ variation coefficient and 1,25 hydroxyvitamin D levels were determined by radioimmunoassay with a $12 \%$ variation coefficient. Twenty-four-hour urinary deoxypyridinoline levels were determined by chemiluminescence (Immulite DPC, Dipesa). The results were expressed in relation to excretion of creatinine with a $14 \%$ variation coefficient.

Densitometric studies were conducted in the lumbar spine (L2-L4) using an X-ray densitometer (DEXA, Lunar Corporation, Madison, WI). The BMD results were expressed in grams per centimeter squared and as peak percentage of bone mass in normal subjects (T-score) and percentage of subjects of the same age and sex (Z-score), depending on the software used in the device.

\section{ACE Inhibitor Polymorphisms}

Coagulated blood was obtained with EDTA. A nuclear pellet was then obtained following the procedure described by John et $\mathrm{al}^{12}$ and frozen at $-20^{\circ} \mathrm{C}$. DNA was obtained from the pellet with the commercial Kit QIAmp Blood Kit (Qiagen, Hilden, Germany). The amount of DNA obtained was assessed by spectrophotometry.

In a final volume reaction of $20 \mu \mathrm{L}$, we used 25 $\mathrm{mmol} / \mathrm{L}$ of each dNTP (Amersham Pharmacia Biotech, Piscataway, NJ), $50 \mathrm{mmol} / \mathrm{L} \mathrm{KCl}, 1.5 \mathrm{mmol} / \mathrm{L} \mathrm{MgCl}_{2}, 10$ $\mathrm{mmol} / \mathrm{L}$ Tris $\mathrm{HCl}$ (at $\mathrm{pH} 9.0$ ); and $0.75 \mathrm{U}$ of Taq DNA polymerase (Amersham Pharmacia Biotech). Using genomic DNA, the specific sequence of insertion/deletion polymorphism of intron 16 of the ACE gene was amplified with 20 pmoles of each of the automatic primers described by Shanmugan et al. ${ }^{13}$ This is a modification of the original procedure by Rigat et $\mathrm{al}^{14}$ designed to flank the inserted segment using a third primer specific for the insertion to prevent the 5\% typing error of both ID and DD genotypes.

Polymerase chain reaction (PCR) was conducted in a Perkin Elmer 9600 thermocycler (Norwalk, CT) where, 
Table 1. Baseline patient characteristics in the three regimes

\begin{tabular}{lccc}
\hline & Quinapril & $\begin{array}{c}\text { Quinapril + } \\
\text { Hydrochlorothiazide }\end{array}$ & Enalapril \\
\hline Age & $59 \pm 10$ years & $59 \pm 8$ years & $59 \pm 11$ years \\
Sex & $34 \% \mathrm{M}, 66 \% \mathrm{~F}$ & $35 \% \mathrm{M}, 65 \% \mathrm{~F}$ & $48 \% \mathrm{M}, 52 \% \mathrm{~F}$ \\
Weight & $71 \pm 13 \mathrm{~kg}$ & $74 \pm 11 \mathrm{~kg}$ & $75 \pm 13 \mathrm{~kg}$ \\
Height & $163 \pm 8 \mathrm{~cm}$ & $159 \pm 7 \mathrm{~cm}$ & $163 \pm 8 \mathrm{~cm}$ \\
Systolic BP & $152 \pm 23 \mathrm{~mm} \mathrm{Hg}$ & $165 \pm 21 \mathrm{~mm} \mathrm{Hg}$ & $155 \pm 20 \mathrm{~mm} \mathrm{Hg}$ \\
Diastolic BP & $91 \pm 9 \mathrm{~mm} \mathrm{Hg}$ & $96 \pm 9 \mathrm{~mm} \mathrm{Hg}$ & $93 \pm 12 \mathrm{~mm} \mathrm{Hg}$ \\
Densitometry (L2-L4) & $1.097 \pm 0.164 \mathrm{~g} / \mathrm{cm}^{2}$ & $1.070 \pm 0.145 \mathrm{~g} / \mathrm{cm}$ & $1.111 \pm 0.174 \mathrm{~g} / \mathrm{cm}^{2}$ \\
T-score & $-0.98 \pm 1.32$ & $-1.19 \pm 1.24$ & $-0.91 \pm 1.39$ \\
Z-score & $-0.09 \pm 1.29$ & $-0.26 \pm 1.37$ & $-0.12 \pm 1.31$ \\
\hline
\end{tabular}

$\mathrm{M}=$ men; $\mathrm{F}=$ women; $\mathrm{BP}=$ blood pressure.

after a 3-min initial denaturation at $93^{\circ} \mathrm{C}$, DNA was subjected to 30 amplification cycles consisting in denaturation for $1 \mathrm{~min}$ at $92^{\circ} \mathrm{C}$, annealing for $1 \mathrm{~min}$ at $60^{\circ} \mathrm{C}$, and elongation for $1 \mathrm{~min}$ at $72^{\circ} \mathrm{C}$, with a final elongation of 7 min at $72^{\circ} \mathrm{C}$. The PCR products were analyzed by $8 \%$ polyacrylamide gel electrophoresis. The PCR products 478 bp-long with insertion (allele I) and $191 \mathrm{bp}$-long in the absence of insertion (ie, in deletion) (allele D) were observed. Insertion-positive subjects (both in homozygotes and in heterozygotes) showed a third band, less intense and slightly smaller than the band with the insertion. This may be due to the specific insertion product.

A second amplification with the specific sequence primer was conducted with samples from patients with a DD genotype following the conditions described by Shanmugan et $\mathrm{al}^{13}$ to confirm that there had been no false allocation of ID and DD genotypes derived from the 5\% amplification of alleles I and D, as described by Shanmugan et $\mathrm{al}^{13}$ in the human ACE gene and by Perna et $\mathrm{al}^{15}$ in the human TPA gene. When using high-quality amplified products, no amplification error was found or performance improved in the presence of dymethilsulphoxide.

\section{Statistical Analyses}

A descriptive statistical analysis, including central and dispersion trends, was conducted for quantitative categories, and absolute and relative variables were analyzed for the different categories. The time point for the efficacy analysis was the termination of the treatment in accordance with the rule of the "Last-observation-Carried-Forward." The Student $t$ test was used to analyze the data that matched the aim of the study, which consisted in comparing the changes in the evolution of the patients. Moreover, Tukey's method was used to compare multiple measurements. The relationship between variables was assessed using Pearson's correlation coefficient. The results are expressed as mean \pm standard deviation.

\section{Ethical Issues}

This study was approved by the hospital's ethics committee and the patients signed an informed consent form.

\section{Results}

The study initially included 134 patients, of whom 96 completed the entire protocol. Reasons for withdrawal were personal (22 cases), 4 cases of vascular complications (ie, cardiac insufficiency, myocardial infarction, stroke), 9 cases of coughing, 2 deaths, and 1 case of headache. Baseline characteristics were similar in all three therapeutic groups and no statistically significant differences were found (Table 1). Moreover, no differences were found between the patients that completed the study and those who withdrew before its completion. All three treatments appeared to be effective in decreasing systolic BP values: quinapril $(152 \pm 23 \mathrm{~mm} \mathrm{Hg} v 138 \pm 16 \mathrm{~mm} \mathrm{Hg}$, $-8 \%)$, quinapril-HCTZ (165 $\pm 21 \vee 143 \pm 16 \mathrm{~mm} \mathrm{Hg}$, $-12.6 \%)$, enalapril (155 $\pm 20 \mathrm{~mm} \mathrm{Hg} v 142 \pm 19 \mathrm{~mm} \mathrm{Hg}$, $-9.3 \%)$. The treatments also decreased diastolic BP values: quinapril (91 $\pm 9 \mathrm{~mm} \mathrm{Hg} v 86 \pm 9 \mathrm{~mm} \mathrm{Hg},-5.3 \%)$, quinapril-HCTZ $(96 \pm 9 \mathrm{~mm} \mathrm{Hg} v 86 \pm 9 \mathrm{~mm} \mathrm{Hg}$, $-9.8 \%$ ), enalapril (93 $\pm 12 \mathrm{~mm} \mathrm{Hg} v 88 \pm 10 \mathrm{~mm} \mathrm{Hg}$, $-4.3 \%$ ). Although no significant differences were observed between the three treatments, quinapril achieved an adequate BP level that became more evident when associated to a thiazide.

\section{Calcium and Phosphorous Homeostasis and Bone Turnover Markers}

The results are shown in Table 2. The three therapeutic groups increased calcium levels in plasma, although this increase was only significant for quinapril and for the combination of quinapril-HCTZ. There were no changes in the levels of phosphorous, osteocalcin, PTHi, and deoxypyridinoline, thus indicating that bone turnover was not modified. An increase of 25-hydroxyvitamin D levels was observed with quinapril $(P=.026)$, although the levels of vitamin $\mathrm{D}$ remained normal in all patients. Active metabolite (1,25-dihydroxyvitamin D) levels decreased in all three groups. However, this decrease was only statistically significant in the group treated with quinaprilHCTZ $(P=.0001)$ and enalapril $(P=.0025)$. The hypocalciuric effect of the antihypertensive treatment was 
Table 2. Phosphorus and calcium metabolism, bone remodeling values, at beginning of treatment and 1 year later

\begin{tabular}{|c|c|c|c|c|c|c|}
\hline & \multicolumn{2}{|c|}{ Quinapril } & \multicolumn{2}{|c|}{$\begin{array}{c}\text { Quinapril + } \\
\text { Hydrochlorothiazide }\end{array}$} & \multicolumn{2}{|c|}{ Enalapril } \\
\hline & Initial & Final & Initial & Final & Initial & Final \\
\hline $\mathrm{Ca}(\mathrm{mg} / \mathrm{dL})$ & $\begin{array}{l}9.5 \pm 0.3 \\
3.4+0.5\end{array}$ & $\begin{array}{l}9.6 \pm 0.3^{*} \dagger \\
3.5+0.7\end{array}$ & $\begin{array}{l}9.4 \pm 0.6 \\
3.4+0.5\end{array}$ & $\begin{array}{l}9.8 \pm 0.4 \dagger \\
3.4+0.5\end{array}$ & $\begin{array}{l}9.6 \pm 0.3 \\
3.4+0.4\end{array}$ & $\begin{array}{l}9.7 \pm 0.3 \\
3.4+0.4\end{array}$ \\
\hline Osteocalcin $(\mathrm{ng} / \mathrm{mL})$ & $28.7 \pm 9.1$ & $29.1 \pm 8.8$ & $24.8 \pm 8.6$ & $22.1 \pm 10.5$ & $26.6 \pm 8.2$ & $27 \pm 12.3$ \\
\hline $\mathrm{PTHi}(\mathrm{pg} / \mathrm{mL})$ & $62 \pm 38$ & $62 \pm 32$ & $56 \pm 23$ & $56 \pm 23$ & $53 \pm 22$ & $63 \pm 40$ \\
\hline $\begin{array}{l}\text { 25-vitamin D } \\
\quad(\mathrm{nmol} / \mathrm{L}) \\
1,25 \text {-vitamin D }\end{array}$ & $46 \pm 22$ & $58 \pm 22 \ddagger$ & $56 \pm 28$ & $58 \pm 21$ & $56 \pm 25$ & $57 \pm 28$ \\
\hline$(\mathrm{nmol} / \mathrm{L})$ & $56 \pm 24$ & $49 \pm 18$ & $64 \pm 23$ & $43 \pm 16 \S$ & $61 \pm 27$ & $42 \pm 19 \|$ \\
\hline Calciuria (mg/24 h) & $248 \pm 193$ & $231 \pm 151$ & $209 \pm 93$ & $161 \pm 939$ & $262 \pm 171$ & $213 \pm 152$ \\
\hline Natriuria (mEq/24 h) & $142 \pm 70$ & $146 \pm 64$ & $139 \pm 67$ & $157 \pm 90$ & $143 \pm 56$ & $143 \pm 68$ \\
\hline $\begin{array}{l}\text { Urinary calcium/ } \\
\text { creatinine }\end{array}$ & $0.19 \pm 0.11$ & $0.20 \pm 0.10$ & $0.21 \pm 0.09$ & $0.17 \pm 0.11^{* *}$ & $0.21 \pm 0.16$ & $0.17 \pm 0.08$ \\
\hline $\begin{array}{l}\text { (nmol/mmol cr) } \\
\text { (nmel }\end{array}$ & $7 \pm 4$ & $7 \pm 3$ & $6 \pm 3$ & $7 \pm 3$ & $6 \pm 5$ & $5 \pm 2$ \\
\hline
\end{tabular}

$\mathrm{Ca}=$ calcium; $\mathrm{P}=$ phosphorus; $\mathrm{PTHi}=$ intact parathyroid hormone.

$* P=.01 ; \dagger P=.001 ; \ddagger P=.026 ; \S P=.0001 ; \| P=.0025 ; \uparrow P=.0022 ; * * P=.04$.

only statistically significant when thiazide was used $(P=$ .002). Nevertheless, a decrease in urinary calcium was observed in all three groups without any significant differences among them.

Throughout the study, statistical analyses were repeated in the whole population ( $n=96$ hypertensive), in women $(n=57)$, in the osteoporotic hypertensive population ( $\mathrm{T}$ $<-2.5)$, and in the population with increased BMD $(n=$ 44 ). The results obtained in these analyses were similar to those described.

\section{BMD, T-Score, and Z-Score}

During the follow-up period of 1 year, BMD remained unchanged and there was no physiologic loss, which is common in this age group. No differences were found among the three groups at the beginning and the end of the treatment: quinapril (1.097 $\pm 0.15 v 1.097 \pm 0.16)$, quinapril-HCTZ $(1.070 \pm 0.14 v 1.073 \pm 0.15)$, enalapril $(1.111 \pm 0.17 v 1.111 \pm 0.19)$. No differences were found when evaluating the T-score: quinapril $(-0.98 \pm 1.32 v$ $-0.98 \pm 1.36)$, quinapril-HCTZ $(-1.19 \pm 1.24 v-1.15$ $\pm 1.24)$, enalapril $(-0.91 \pm 1.39 v-0.89 \pm 1.36)$; or the Z-score: quinapril $(-0.07 \pm 1.29 v-0.1 \pm 1.37)$, quinapril-
HCTZ $(-0.26 \pm 1.37 v-0.2 \pm 1.39)$, enalapril $(-0.12$ $\pm 1.31 v-0.22 \pm 1.49)$. Bone mass had a statistically significant correlation with osteocalcin $(r=-0.25, P=$ $.016)$ and calcium/creatinine ratio $(r=-0.23, P=.026)$ values. Nevertheless, no correlation was observed with systolic BP or diastolic BP values. At the end of the study, bone mass showed no relationship with any of the laboratory parameters. Because no BMD differences were found, patients could be divided into groups according to their genotypes.

\section{Polymorphisms and Bone Mass Evolution}

Polymorphisms were evaluated in 69 patients with the following results: 12 patients were II (17\%), 31 were ID (45\%), and 26 were DD (38\%). The percentage of allele I was $40 \%$ whereas the percentage of allele D was $60 \%$. Table 3 shows the relationship between polymorphisms and the response of BMD to antihypertensive treatment. No differences were observed among men. However, women with II+ID polymorphism showed a higher initial BMD and a statistically significant decrease in BMD after the treatment with ACE inhibitors, whereas women with DD polymorphism showed the opposite effect. A benefi-

Table 3. Bone mass response to antihypertensive treatment according to patient's sex and polymorphism

\begin{tabular}{lccccc}
\hline & \multicolumn{2}{c}{ II + ID } & & DD & \\
\cline { 2 - 5 } & $\begin{array}{c}\text { Male } \\
(\boldsymbol{n}=\mathbf{1 5})\end{array}$ & $\begin{array}{c}\text { Female } \\
(\boldsymbol{n}=\mathbf{2 9})\end{array}$ & & $\begin{array}{c}\text { Male } \\
(\boldsymbol{n}=\mathbf{1 2})\end{array}$ & $\begin{array}{c}\text { Female } \\
(\boldsymbol{n}=\mathbf{1 3})\end{array}$ \\
\hline BMDi $\left(\mathrm{g} / \mathrm{cm}^{2}\right)$ & $1.136 \pm 0.15$ & $1.081 \pm 0.16$ & & $1.148 \pm 0.16$ & $1.040 \pm 0.15$ \\
BMDf $\left(\mathrm{g} / \mathrm{cm}^{2}\right)$ & $1.147 \pm 0.16$ & $1.064 \pm 0.16 *$ & & $1.158 \pm 0.20$ & $1.070 \pm 0.16 \dagger$ \\
\hline
\end{tabular}

$\mathrm{BMDi} / \mathrm{BMDf}=$ initial/final bone mineral density.

$* P=.034 ;+P=.017$. 
cial effect of ACE inhibitors was observed in DD genotype patients.

\section{Discussion}

In addition to controlling BP, the three therapeutic regimes maintained a stable BMD, registering no BMD decrease. This demonstrates the beneficial effect of ACE inhibitors, as the average bone mass loss in this population group is higher than $0.5 \%$ every year. This loss can reach $<3 \%$ in postmenopausal women. The presence of thiazides does not increase the effect of ACE inhibitors on BMD, bone turnover markers, and calcium metabolism homeostasis parameters. Nevertheless, no difference was found when the decreases measured in all three groups were compared. The analysis of the overall hypertensive population included in the study revealed that all three treatments had a beneficial effect on the primary phosphorus and calcium metabolism alterations described in hypertension (eg, decrease in calcemia and hypercalciuria, and increase in the calcium/creatinine ratio).

Interestingly, there is a lack of information on the long-term effects of antihypertensive treatment, although $50 \%$ of the hypertensive population is made up of postmenopausal women. Most studies analyzed the effects of thiazides and, to a lesser degree, the effects of calcium antagonists, whereas very few studies analyzed the effects of ACE inhibitors.

Several observational studies proved that hypertensive subjects treated with thiazides presented a higher BMD (mainly cortical bone) and fewer fractures, although not all of them showed the similar data. ${ }^{8,16,17}$ In randomized studies conducted with hypertensive and nonhypertensive subjects, an increase in cortical bone was observed without changes in the lumbar spine and the femoral neck. ${ }^{18,19}$ These data agree with the results of our study. We did not observe an increase in BMD at a trabecular level. Thiazides could act directly on the cells participating in bone turnover (ie, osteoblasts, osteoclasts) or indirectly by decreasing the renal excretion of calcium and achieving a positive balance of such excretion. ${ }^{20,21}$ An aspect that has been described, and also seen in our study, consists of a decrease in vitamin $\mathrm{D}$ active metabolite concentrations. Such a decrease has been negatively related to bone mass. The reason for such a decrease is still unclear. ${ }^{22}$

The effect of calcium antagonists on the skeleton has hardly been studied. The administration of nitrendipine for 1 year did not modify lumbar spine bone mineral density and decreased calcitonin plasma concentration. ${ }^{23}$ Nifedipine caused a decrease in calcitonin levels that was similar to the effects obtained with nisoldipine. ${ }^{24}$ Nevertheless, none of these studies measured BMD and the number of patients was small.

However, few studies analyzed the effects of ACE inhibitors on BMD. In fact, we found no clinical studies on humans studying this effect in the literature. In a 16-week study, Townsend et $\mathrm{al}^{25}$ did not observe any effects of captopril on calcium homeostasis parameters. In a study using ovariectomized rats, moexepril did not modify either the trabecular or the cortical bone. Long- and short-term effects were evaluated in normotensive and hypertensive rats. ${ }^{26,27}$ Our study is the first that prospectively assesses the effects of ACE inhibitors on bone mass and calcium metabolism parameters in a hypertensive population. In these patients, a beneficial effect was observed because BMD loss was avoided and the metabolic profile was improved.

This therapeutic group acts by blocking angiotensin II synthesis. Consequently, it has a beneficial effect on the skeleton because there is a decrease in angiotensin concentration. It has been hypothesized that angiotensin can indirectly act on bone cells by regulating the flow of bone marrow capillaries ${ }^{28}$ or directly by binding to $\mathrm{AT}_{1}$ receptors located on osteoblasts, thus promoting the mediator release that would activate the osteoclasts. ${ }^{29} \mathrm{We}$ can consider the effect on osteoblasts as contradictory: they stimulate DNA synthesis, the number of cells and collagen synthesis by osteoblastic precursors; however, decreasing the mineralization of mature osteoblasts. ${ }^{30,31}$ The reduction of angiotensin II levels has a beneficial effect of inhibiting bone resorption and promoting mineralization.

Angiotensin II can interfere with calcium metabolism. The administration of this peptide in a group of healthy volunteers caused a decrease in ionic calcium levels and an increase in PTHi levels. ${ }^{32}$ The decrease of calcemia was not related to an increase in calciuria, but it could be caused by an increase in calcium uptake by vascular smooth muscle cells. ${ }^{33}$ In our patients, ACE inhibitors increased the level of calcium, although the concentration of PTHi was not modified. These data suggest a beneficial effect on the blockage of the synthesis of angiotensin in calcium metabolism.

All previous data suggest the possible existence of an renin-angiotensin-aldosterone system at the level of the bone tissue where angiotensin II can have a deleterious effect, both at a cellular and a humoral level. By diminishing angiotensin II concentration, the ACE blockage would have a beneficial effect on the skeleton.

Angiotensin converting enzyme is a metallopeptidase that controls the conversion of angiotensin I to angiotensin II, and a polymorphism (I/D) has been described where the presence of the insertion allele is associated with a decrease in serum and tissue enzymatic activity, whereas allele $\mathrm{D}$ is related to an increased activity. This led us to believe that the possible beneficial effect of enzymatic blockage could be related to ACE polymorphism, and, consequently, to the enzyme levels in the serum. In the study population we found a polymorphism percentage similar to that described for the Spanish population, either hypertensive or nonhypertensive. ${ }^{10}$ After analyzing our data we combined the II and ID populations because it had been demonstrated that there were no statistically significant differences between the ACE levels in these two groups. ${ }^{34} \mathrm{We}$ only saw a relationship between polymor- 
phisms and bone mass in women, a population in which osteoporosis is more relevant. The increase in bone mass after the hypertensive treatment occurred in DD polymorphism, where the enzyme activity was more effectively blocked and the angiotensin II levels would decrease further. Baseline BMD was lower in this population group because the initial concentration of angiotensin II was higher. This effect was only found in women. A similar relationship was observed when assessing the antiproteinuric effects of ACE inhibitors and polymorphism. ${ }^{35,36}$ Woods et al ${ }^{11}$ obtained different results when assessing the response of BMD to hormone replacement therapy, which was better in polymorphism II. Nevertheless, we must take into account that both the population studied (nonhypertensive) and the drugs used were different. This is the first study that shows the involvement of the ACE gene in BMD levels in hypertensive women and the improvement of BMD by ACE inhibitors in a group of this population.

In our study we used two ACE inhibitors, quinapril and enalapril. Enalapril was used to confirm whether the effect of quinapril was a class effect (ACE inhibitors) or caused exclusively by the drug. No statistically significant differences were observed between these two ACE inhibitors, except for calcemia and vitamin D. Quinapril increased calcium and vitamin $\mathrm{D}$ levels, thus indicating the existence of a more favorable metabolic profile for its use in hypertensive patients with an associated osteoporosis. However, when evaluating this information, it must be borne in mind that the number of patients in the study is relatively small and that not all of them were included in the same period. Therefore, seasonal variations of vitamin D levels may have occurred. The three drugs lowered the levels of 1,25 vitamin $\mathrm{D}$. An inverse relationship has been described between renin and 1,25 vitamin D levels ${ }^{37}$ and plasma renin levels are increased due to the fact that ACE inhibitors stop the conversion of angioten$\sin$ I into angiotensin II.

\section{Limitations of the Study}

The main limitation of this study was the relatively small number of subjects studied. However, the percentage of polymorphisms reflects the percentage of in the Spanish population. A follow-up period of 1 year limited the observation of significant changes in BMD, and the nonassessment of osteoporotic fractures. Furthermore, it was not possible to establish a control group treated with placebo because the characteristics of the study population made this alternative ethically unfeasible.

The study was not designed to assess the antihypertensive efficacy of the treatments. Thus, this study lacks statistical power to establish differences between the treatments, only $57 \%$ (statistical power).

\section{References}

1. McCarron DA, Pingree PA, Rubin RJ, Gaucher SM, Molitch M, Krutzik S: Enhanced parathyroid function in essential hypertension:
A homeostatic response to a urinary calcium leak. Hypertension 1980;2:162-168.

2. Resnick LM, Laragh JH, Sealey JE, Alderman MH: Divalent cations in essential hypertension. Relations between serum ionized calcium, magnesium, and plasma renin activity. N Engl J Med 1983;309: 888-891.

3. Resnick LM, Muller FB, Laragh JH: Calcium regulating hormones in essential hypertension: Relation to plasma renin activity and sodium metabolism. Ann Int Med 1986;105:649-654.

4. Brickman AS, Nyby MD, Von Hungen K, Eggena P, Tuck ML: Calcitropic hormones, platelet calcium and blood pressure in essential hypertension. Hypertension 1990;16:512-522.

5. McCarron DA: Low serum concentrations of ionized calcium in patients with hypertension. N Engl J Med 1982;307:226-228.

6. Gadallah M, Massry SG, Bigazzi R, Horst RL, Eggena P, Campese VM: Intestinal absorption of calcium and calcium metabolism in patients with essential hypertension and normal renal function. Am J Hypertens 1991;4:404-409.

7. Cappuccio FP, Meilahn E, Zmuda JM, Cauley JA: High blood pressure and bone mineral loss in elderly white women: A prospective study. Lancet 1999;354:971-975.

8. Ray WA, Downey W, Griffin MR Melton LJ III: Long-term use of thiazide diuretics and risk of hip fracture. Lancet 1989;1:687-690.

9. Puig JC, Mateos FA, Ramos TH, Lavilla MP, Capitan MC, Gil A: Albumin excretion rate and metabolic modifications in patients with essential hypertension. Effects of two angiotensin converting enzyme inhibitors. Am J Hypertens 1994;7:46-51.

10. Giner V, Corella D, Chaves FJ, Pascual JM, Portoles O, Marin P, Lozano JV, Armengod ME, Redón J: Polimorfismos genéticos del sistema renina-angiotensina e hipertensión arterial esencial en la población española. Med Clin (Barc) 2001;117:525-529.

11. Woods D, Onambele G, Woledge R, Skelton D, Bruce S, Humphries SE, Montgomery H: Angiotensin I converting enzyme genotype-dependent benefit from hormone replacement therapy in isometric muscle strength and bone metabolism density. J Clin Endocrinol Metab 2001;86:2200-2204.

12. John SWM, Weitzner G, Rozen R, Scriver CR: A rapid method for extracting genomic DNA from leukocytes. Nucleic Acids Res 1991; 19:408.

13. Shanmugan V, Sell KW, Saha BK: Mistyping ACE heterozygotes. PCR Methods and Applications 1993;3:120-121.

14. Rigat B, Hubert P, Corvol P, Soubrier F: PCR detection of the insertion/deletion polymorphism of the human angiotensin converting enzyme gene (DCP1) (dipeptidyl carboxypeptidase 1). Nucleic Acids Res 1992;20:1433.

15. Perna NT, Batzer MA, Deininger PL, Stoneking M: Alu insertion polymorphism: A new type of marker for human population studies. Hum Biol 1992;64:641-648.

16. Cauley JA, Cummings SR, Seeley DG, Black D, Browner W, Kuller LH, Nevitt MC: Effects of thiazide diuretic therapy on bone mass, fractures and falls. The Study of Osteoporotic Fracture Research Group. Ann Intern Med 1993;118:666-673.

17. Lacroix Az, Wienpahl J, White LR, Wallace RB, Scherr PA, George LK, Cornoni-Hantley S, Ostfeld AM: Thiazide diuretics agents and the incidence of hip fracture. N Engl J Med 1990;322:286-290.

18. Wasnich RD, Davis JW, He YF, Petrovich H, Ross PD: A randomized, double-masked, placebo-controlled trial of chlorthalidone and bone loss in elderly women. Osteoporosis Int 1995;5:247-251.

19. Reid IR, Ames RW, Orr-Walker BJ, Clearwater JM, Home AM, Evans MC, Murray MA, McNeil AR, Gamble CG: Hydrochlorothiazide reduce loss of cortical bone in normal postmenopausal women: A randomized controlled trial. Am J Med 2000;309:362-370.

20. Hall TJ, Schaueblin M: Hydrochlorothiazide inhibits osteoclastic bone resorption in vitro. Calcif Tissue Int 1994;55:266-268.

21. Aubin R, Menard P, Lajeunesse D: Selective effect of thiazides on the human osteoblast-like cell line MG-63. Kidney Int 1996;50: $1476-1482$. 
22. Sowers MR, Wallace RB, Hollis BW: The relationship of 1,25dihydroxyvitamin D and radial bone mass. Bone Miner 1990;10: 139-148.

23. Giles TD, Sander GE, Roffidal LE, Quiroz AC, Mazzu AL: Comparative effects of nitrendipine and hydrochlorothiazide on calciotropic hormones and bone density in hypertensive patients. Am J Hypertens 1992;5:875-879.

24. Zofkova I, Kancheva RL: The effect of nifedipine on serum parathyroid and calcitonin in postmenopausal women. Life Sci 1995;57: 1087-1096.

25. Townsend R, DiPette DJ, Evans RR, Davis WR, Green A, Graham GA, Wallace JM, Holland OB: Effects of calcium channel blockade on calcium homeostasis in mild to moderate essential hypertension. Am J Med Sci 1990;300:133-137.

26. Stimpel M, Jee WS, Ma Y, Yamamoto N, Chen Y: Impact of antihypertensive therapy on postmenopausal osteoporosis: Effects of the angiotensin converting enzyme inhibitor moexipril, $17 \beta$-estradiol and their combination on the ovariectomy-induced cancellous bone loss in young rats. J Hypertens 1995;13:1852-1856.

27. Ma Y, Stimpel M, Liang H, Pun J, Jee WS: Impact of antihypertensive therapy on the skeleton: effects of moexipril and hydrochlorothiazide on osteopenia in spontaneously hypertensive ovariectomized rats. J Endocrinol 1997;154:467-474.

28. Hatton R, Stimpell M, Chambers TJ: Angiotensin II is generated from angiotensin I by bone cells and stimulates osteoclastic bone resorption in vitro. J Endocrinol 1997;152:5-10.

29. Hiruma Y, Inoue A, Hirose S, Hagiware H: Angiotensin II stimulates the proliferation of osteoblast-rich populations of cells from rat calvariae. Biochem Biophys Res 1997;230:176-178.

30. Hagiwara H, Hiruma Y, Inoue A, Yamaguchi A, Hirose S: Decel- eration by angiotensin II of the differentiation and bone formation of rat calvarial osteoblastic cells. J Endocrinol 1998;156:543-550.

31. Lamporter S, Kling L, Scharader M, Ziegler R, Pfeilschifter J: Effects of angiotensin III on bone cells in vitro. J Cell Physiol 1998;170:89-98.

32. Grant FD, Mandel SJ, Brown EM, Williams GH, Seely EW: Interrelationships between the renin-angiotensin-aldosterone and calcium homeostatic systems. J Clin Endocrinol Metab 1992;75:988992.

33. Brock TA, Alexander RW, Ekstein LJ, Atkinson WJ, Gimbrone MA: Angiotensin increases cytosolic free calcium in cultured vascular smooth muscle cells. Hypertension 1985;7(Suppl I):105.

34. Danser AHJ, Schalekamp MADH, Bax WR, Van der Brink AM, Saxene PR, Riegger GA, Schunkert H: Angiotensin converting enzyme in the human heart effect of the deletion/insertion polymorphism. Circulation 1995;92:1387-1388.

35. Yoshida H, Mitarai T, Kawamura T, Kitajima T, Miyazaki Y, Nagasawa R, Kawaguchi Y, Kubo H, Ichikawa I, Sakai O: Role of the deletion polymorphism of the angiotensin converting enzyme gene in the progression and the therapeutic responsiveness of Ig A nephropathy. J Clin Invest 1995;96:2162-2169.

36. Moriyama T, Kitamura H, Ochi S, Izumi M, Yokoyama K, Yamauchi A, Veda N, Kamada T, Inai E: Association of angiotensin I-converting enzyme gene polymorphism with susceptibility to antiproteinuric effect of angiotensin I-converting enzyme inhibitors in patients with proteinuria. J Am Soc Nephrol 1995;6:1674-1678.

37. Burgess ED, Hawkins RG, Wanatabe M: Interaction of 1,25-dihydroxivitamin D and plasma renin activity in high renin essential hypertension. Am J Hypertens 1990;3:903-905. 